\title{
A Retrospective and Prospective Analysis of the West African Ebola Virus Disease Epidemic: Robust National Health Systems at the Foundation and an Empowered WHO at the Apex
}

\author{
Lawrence O. Gostin \\ Georgetown University Law Center, gostin@law.georgetown.edu \\ Eric A. Friedman \\ Georgetown University Law Center, eaf74@law.georgetown.edu
}

WHO Reform Timeline is attached at the end of the article.

This paper can be downloaded free of charge from:

https://scholarship.law.georgetown.edu/facpub/1482

http://ssrn.com/abstract=2604976

385 Lancet 1902-1909 (2015)

This open-access article is brought to you by the Georgetown Law Library. Posted with permission of the author. Follow this and additional works at: https://scholarship.law.georgetown.edu/facpub

Part of the Health Law and Policy Commons, Health Policy Commons, International Public Health Commons, Public Policy Commons, and the Virus Diseases Commons 


\title{
(Q) A retrospective and prospective analysis of the west African Ebola virus disease epidemic: robust national health systems at the foundation and an empowered WHO at the apex
}

\author{
Lawrence O Gostin, Eric A Friedman
}

Lancet 2015; 385: 1902-09

See Comment page 1805

O'Neill Institute for National and Global Health Law, Georgetown University Law Center, Washington, DC, USA (Prof LO Gostin JD, E A Friedman JD) Correspondence to: Prof Lawrence O Gostin, O'Neill Institute for National and Global Health Law, Georgetown University Law Center, Washington, DC 20001, USA gostin@law.georgetown.edu

The Ebola virus disease outbreak in west Africa is pivotal for the worldwide health system. Just as the depth of the crisis ultimately spurred an unprecedented response, the failures of leadership suggest the need for innovative reforms. Such reforms would transform the existing worldwide health system architecture into a purposeful, organised system with an empowered, highly capable WHO at its apex and enduring, equitable national health systems at its foundation. It would be designed not only to provide security against epidemic threats, but also to meet everyday health needs, thus realising the right to health. This retrospective and prospective analysis offers a template for these reforms, responding to the profound harms posed by fragile national health systems, delays in the international response, deficient resource mobilisation, ill defined responsibilities, and insufficient coordination. The scope of the reforms should address failures in the Ebola response, and entrenched weaknesses that enabled the epidemic to reach its heights.

\section{Introduction}

The Ebola virus disease outbreak in west Africa affected impoverished post-conflict countries with weak health systems and no experience with Ebola. The location could hardly have been worse. The initial outbreak occurred near Guinea's border with Liberia and Sierra Leone, enabling rapid transnational spread. Unsafe burial practices became "underground transmission chains", and, for the first time, the virus became embedded in congested urban areas.

The unfamiliarity of Ebola delayed its detection. In December, 2013, Ebola first appeared in a 2-year-old child, ${ }^{2}$ but Guinean health officials misdiagnosed initial cases and Ebola was not confirmed in Guinea until March 21, 2014, and in Liberia 2 days later (see figure appendix). ${ }^{3}$ In Sierra Leone, scientists suspected Ebola, ${ }^{4}$ but their information did not reach surveillance teams and Ebola remained unconfirmed until late May. These missed initial diagnoses and a second wave of Ebola that hit Liberia in June were ultimately linked to the funeral of a traditional healer in Guinea in March. ${ }^{4}$

In states rife with corruption and low health literacy, distrust of government and health workers was pervasive, and exacerbated by the early methods of response. Health workers arrived in unfamiliar, spacesuit-like clothing, frightening residents. The ill were removed from their communities, sometimes never to be seen again. In August, 2014, Liberia deployed the military to enforce a cordon sanitaire in West Point, Monrovia, provoking violence. ${ }^{5}$ A month later, Sierra Leone declared a 3-day curfew, a so-called lockdown, using it as an opportunity for house-to-house education. In Guinea, rumours persisted that the government had fabricated Ebola as a ploy to gain humanitarian aid. ${ }^{6}$ Patients were stigmatised, undermining crucial opportunities to use the resource that survivors could be to their communities. ${ }^{7.8}$ The governments' early actions were the wrong way to change behaviour. Families hid feverish individuals, unsafe burial practices persisted, and there was violence against health workers, educators, and police. ${ }^{6,9}$

By late June, 2014, Ebola was confirmed in 60 locations across three countries, with cases rising exponentially, and health workers were dying in large numbers. ${ }^{10}$ Yet the international machinery did not move into higher gear until late July, after the medical evacuation of two US aid workers from Liberia. By this point, the disease had spread to the Nigerian megacity of Lagos, provoking fears of unmitigated disaster. The polio vaccination infrastructure in Nigeria was re-purposed, rapidly containing the outbreak. ${ }^{11}$ In the ensuing months, Ebola spread to Senegal, Mali, the USA, and the UK, but was controlled.

WHO issued a regional plan, asking the international community to fill a US\$71 million gap, ${ }^{12}$ the first in a succession of rising cost estimates, reaching $\$ 988$ million in a UN appeal in mid-September. ${ }^{13}$ Controversy arose over the ethical allocation of therapies after several Americans and a Spanish national, rather than west Africans, received doses of the scarce ZMapp, an experimental biopharmaceutical.

It was not until Aug 8, $2014-4.5$ months after the first international spread-that the WHO Director-General declared a Public Health Emergency of International Concern (PHEIC) under the 2005 International Health Regulations (IHR), a global treaty. ${ }^{14}$ Yet Médecins Sans Frontières had warned on June 21 that Ebola was "out of control", calling for a "massive deployment of resources". ${ }^{10}$ WHO's staff recognised the urgency of the crisis, but expressed concern about the economic and political ramifications for the affected states. ${ }^{15}$

International donations finally began to flow, with the largest contributions from the World Bank and the USA. Building on historical ties, US assistance focused on Liberia, British assistance on Sierra Leone, and French assistance on Guinea. On Sept 16, 2014, President Obama mobilised military assets-3000 troops to support logistics, train health workers, and build 17 treatment centres. 
2 days later, the UN Security Council passed an unprecedented resolution calling Ebola a threat to international peace and security, urging an escalated response and an end to travel restrictions, which several states had enacted. ${ }^{16}$ The next day, the UN SecretaryGeneral announced the UN Mission for Emergency Ebola Response (UNMEER) to lead operations in the region. ${ }^{17}$

Fear increased in October when the US Centers for Disease Control and Prevention (CDC) posited a worst-case scenario of 1.4 million infections by mid-January, 2015. ${ }^{18}$ Travel bans and flight suspensions harmed fragile economies and hampered the flow of trade and aid. On Sept 30, public fear intensified in the USA when health workers in Dallas, TX, diagnosed Ebola in a traveller originating in Liberia. ${ }^{19}$ Two Dallas nurses contracted the virus. Soon thereafter, a medical worker returning from Guinea to New York City was diagnosed with Ebola. ${ }^{20}$ President Obama resisted calls for a travel ban, but erected rigorous entry screening, and several states quarantined health workers returning from the region. ${ }^{21}$

Yet the global response was taking hold, and communities mobilised, leading to substantial changes in behaviour. By Dec 1, 2014, in most of the region UNMEER reached its targets of $70 \%$ safe burials and $70 \%$ of new patients with Ebola in treatment facilities. ${ }^{22}$ The US Congress passed the President's emergency appropriation of $\$ 5.4$ billion. ${ }^{23}$ By February, international contributions neared $\$ 5$ billion from 70 countries, ${ }^{24,25}$ although UNMEER reported a shortfall of nearly $\$ 1$ billion through June $2015 .^{26}$

The world would soon embark on the next phase of "getting to zero"-no new cases. ${ }^{27}$ Having peaked in September, Liberia's new cases fell to fewer than ten per week in January, with one new case in March. After a spike in November and December, new cases in Sierra Leone declined significantly, with progress in Guinea, although distrust continued to hinder the response there. ${ }^{28,29}$ Until there are zero cases, the epidemic is not over. Reasonable concerns persist that Ebola could become endemic in Guinea and Sierra Leone, or re-emerge in Liberia. There remains the crucial task of recovery and development, because Ebola has devastated the region.

\section{A new global health framework}

The Ebola epidemic revealed a fragmented global health system: an ad hoc series of institutions, laws, and strategies that do not function as a coherent whole. Ebolaaffected countries had neither the health infrastructure nor specialised capacity to respond. WHO fell short of its leadership responsibilities, ${ }^{30}$ and the IHR - the governing legal framework-displayed deficiencies. Health workers and funding needed immediately instead arrived slowly and unpredictably.

Drawing on the lessons of Ebola, we propose a global health framework with robust national health systems at its foundation and an empowered WHO at its apex, well coordinated funding and actions from many parties, effective legal methods to establish clear accountability, and shared responsibility to build core capacities. Although our lens is pandemic preparedness, system capabilities should extend to the full range of health needs.

\section{National health systems: a strong foundation}

Liberia, Sierra Leone, and Guinea have among the world's weakest health systems, shown by the severe shortage of health workers. International recommended thresholds for doctors, nurses, and midwives range from 223 (WHO) to 345 (International Labour Organization) per 100000 population. ${ }^{31}$ The Ebola-affected countries have about one-fifth to less than one-tenth of these recommendations. ${ }^{32,33}$ Moreover, health workers are heavily concentrated in urban areas, and in this instance Ebola devastated an already deficient workforce, killing more than 500 health workers through April, 2015. ${ }^{29}$

Human resource shortages sharply curtailed health care beyond Ebola. Fearing infection and without the necessary personal protective equipment and safety protocol training, many health workers stayed away from their hospitals and clinics, as did ill patients, fearing contagion. Short of staff or unprepared for Ebola patients they received, many health facilities closed. Governments concentrated scarce health resources on the Ebola emergency. During the outbreak, more deaths probably ensued from other causes than from Ebola. Patients with Ebola received a standard of care far less than that offered in higher-income countries, lacking basic diagnostics and fluid replacement that would have improved survival rates. ${ }^{34}$

The Ebola outbreak exposed health system fragilities: poor infection control put health workers at risk and dissuaded patients from seeking treatment; communitybased health workforces were insufficient, and therefore unable to detect unusual symptoms or patterns, educate the community, or trace contacts; and public distrust reinforced rumours, impeding behaviour change. The Ebola epidemic taught us that recommended public health capacities-required under the IHR but widely ignored-are crucial in bringing health emergencies under control, and keeping populations healthy and safe.

\section{Global health leadership: an empowered WHO}

A global health leader steers the overall direction of epidemic response, drives consensus toward a coherent strategy, ensures all necessary functions are satisfied, and coordinates many participators. Leadership is WHO's primary constitutional mission- “the directing and coordinating authority on international health work" (article 2[a]). In emergencies, the constitution directs the organisation to furnish "necessary aid upon the request or acceptance of Governments" (article 2[d]). ${ }^{35}$ The IHR establishes WHO as the governing institution charged with preventing and responding to global health emergencies.

The Ebola outbreak in west Africa should have been the type of moment for which WHO was created. Instead, the epidemic exposed long-understood failings. Lapses during 
the early stages of Ebola provoked justified criticism and created a unique impetus for reform. At its special session in January, 2015, the Executive Board embraced innovative reforms, though neglected others. ${ }^{36}$ The reform priorities below could enable WHO to become the global health leader envisaged at its creation in 1948, and what the world needs today.

\section{Three crucial functions: technical, normative, and operational}

Historically, WHO excelled in its technical function, with in-house expertise in addition to networks of scientists and collaborating centres. WHO scientific guidelines and in-country assistance are highly respected. In May, 2011, however, WHO experienced a half-billion dollar budget cut, losing 300 headquarter jobs. ${ }^{37,38}$ WHO's emergency response unit lost nearly two-thirds of its staff; ${ }^{39}$ the Regional Office for Africa (AFRO) lost nine of 12 emergency response specialists. ${ }^{4}$ Restoring trust in WHO's unmatched technical skills will require the organisation to attract and retain the highest calibre scientific personnel.

WHO was founded as a normative organisation uniquely positioned for global health diplomacy, with unparalleled treaty-making powers. Yet in 65 years of existence, it has negotiated only two major treaties, the IHR and the Framework Convention on Tobacco Control. WHO should exercise its constitutional powers to set priorities, mobilise action, and monitor and promote compliance with global norms. ${ }^{40}$

WHO's operational function has been most controversial, with some experts proposing a separate organisation to lead operations. ${ }^{41}$ Yet, diluting WHO's operational responsibilities would be an error of judgment. No other entity can match WHO's international legitimacy, partnerships, ties with health ministries, or legal authority. Structural reforms to support operational capacities would restore WHO's most valuable yet diminished asset, trust.

\section{Funding commensurate with a global mandate}

As of March, 2015, Ebola was on track to cost $\$ 6$ billion in direct expenses and at least $\$ 15$ billion in economic losses. ${ }^{26,42,43}$ Recovery plans for Guinea, Liberia, and Sierra Leone developed in April, 2015, total more than $\$ 4.5$ billion over the next several years. ${ }^{446}$ The direct costs alone amount to 3 years of funding for WHO, and is well over 20 times the cost of WHO's emergency response cuts in its $2014-15$ budget. $^{38}$

Inadequate epidemic preparedness funding has been, and will continue to be, unwise. The WHO 2014-15 budget of less than $\$ 4$ billion is wholly incommensurate with its worldwide responsibilities. Further, WHO depends on voluntary contributions for nearly $80 \%$ of its budget, with most contributions earmarked. ${ }^{38}$ Member states should act as stakeholders in the organisation's success by doubling its budget over 5 years, with at least
$50 \%$ composed of mandatory accessed dues. The Secretariat should develop a time-bound plan to match the budget's size and composition with its essential functions. Ultimately, member states will shoulder the cost-either by sustainably increasing assessed contributions or in humanitarian assistance as outbreaks spiral out of control. They should choose to empower, rather than eviscerate, WHO.

\section{Regional governance: speaking and acting with a common goal}

The poor cohesiveness between headquarters and AFRO became evident during Ebola. AFRO did not convene health ministers or open a regional coordination centre until 3 months after Ebola was confirmed in Guinea; the Guinea country office reportedly impeded aid and technical assistance; and Assistant Director-General Bruce Aylward notified the Director-General that international partners believed WHO was "compromising rather than aiding" the mission.,3,47 A representative of Médecins Sans Frontières said, "There is no one to take responsibility, absolutely no one, since the beginning of the crisis". ${ }^{39}$

A strong regional framework begins with top-quality, accountable leaders working constructively with partners. Yet WHO's Regional Committees nominate the Regional Director, with the Executive Board rubberstamping their appointments. ${ }^{48}$ This process makes directors accountable first to their region's health ministers, rather than headquarters, impeding WHO's ability to speak and act as a single organisation.

WHO should return to its constitutional origins, whereby the Executive Board appoints regional directors. ${ }^{35}$ A search committee would create a short-list, using transparent selection criteria. ${ }^{48}$ Regions should, as in Europe, adopt a code of conduct to guide the nomination process. ${ }^{49}$ These reforms would ensure qualified regional directors, well versed in their region's priorities, but accountable to headquarters and committed to WHO's global priorities and programme of work..$^{50,51}$

\section{Civil society engagement}

WHO, as an intergovernmental agency, has an uncertain relationship with non-state parties..$^{52}$ When dealing with the private sector in particular, it needs to avoid conflicts of interest. Conflict management alone, however, cannot lift WHO into the modern era. The AIDS pandemic showed the power of civil society advocacy and ingenuity. To participate in WHO governance forums, civil society organisations must enter into "official relations" with WHO, requiring them to be "international in membership and/or scope", which excludes poorer, grassroots organisations based in developing countries.52 Even if civil society organisations are in official relations, they cannot fully have their voices heard, which underscores the Director-General's 2013 observation, "no proactive, structured means [exist] through which WHO can seek the views of relevant [non-governmental organisations]. ${ }^{{ }^{33}}$ 
The World Health Assembly should enable civil society organisations to participate meaningfully in WHO policy making, including through hearings, focus groups, and input into governance decisions. Newer public-private partnerships (Global Fund for AIDS, Tuberculosis and Malaria and GAVI Alliance) and UNAIDS include civil society representation on their governing boards-a useful model for WHO.

\section{Human resources}

The Executive Board recognised "WHO's human resources systems and processes slowed down the response to Ebola", ${ }^{36}$ calling for reform of recruitment, training, performance reviews, and mobility policies, and affirming the Director-General's authority over regional and country staff. ${ }^{36}$ WHO's managerial and leadership capabilities need to be "valued in the same way as technical capability". ${ }^{54}$ Skills in law, diplomacy, trade, economics, and anthropology are crucial to epidemic preparedness. Only 3\% of WHO non-support staff have these non-medical specialisations. ${ }^{55}$

\section{Stakeholders}

In a well functioning global health system, all parties would perform functions suited to their mandate, working cooperatively, and supporting national ownership. International organisations, states, non-governmental organisations, and the private sector are pivotal stakeholders.

\section{UN}

In September, 2014, the UN assumed leadership in the Ebola response as WHO floundered. For the first time, the Security Council declared an outbreak a "threat to international peace and security" ${ }^{16}$ The Council's binding resolution directed states to lift border and travel restrictions and maintain transportation links. A day after the Security Council resolution, the Secretary-General created UNMEER, the first UN mission to respond to a public health emergency. Charged with "effective ground-level leadership and operational direction", ${ }^{17}$ UNMEER coordinated participants and adopted anthropological-based strategies to change behaviour. ${ }^{56}$

The UN's historic action galvanised political support. By contrast with IHR recommendations, Security Council resolutions are legally binding, with members agreeing "to accept and carry out [the Security Council's] decisions". ${ }^{57}$ If UN action becomes a staple of global health security in the future, the Security Council could specify states' humanitarian responsibilities, which could improve compliance. Raising epidemic response to a level of high politics-through the UN, G7, or G20could transform the global response.

\section{The World Bank}

The World Bank made major contributions, initially $\$ 200$ million in August, 2014, with its total funding exceeding $\$ 1.6$ billion by mid-April, 2015. ${ }^{58,59}$ These grants and loans extend beyond the direct Ebola response, rebuilding health systems, social safety nets, and agriculture. ${ }^{58}$ The World Bank galvanised political support by estimating the economic harms. ${ }^{60}$ In October, the World Bank's President, Jim Yong Kim, proposed a global pandemic emergency facility, discussed later in this paper.

The Bank's role in health and development is distinct from other international organisations. With unique strengths in economic acumen, financial sector networks, and disbursement of funding across sectors, it is uniquely positioned to mobilise multisectoral financing, calculate the economic costs of failures in pandemic preparedness, and develop innovative financing mechanisms.

\section{States}

States hold a primary duty to safeguard their population's health, with a shared international responsibility to fill gaps in capacity. International financial assistance for Ebola came mainly from wealthier states: the USA contributed more than $\$ 1$ billion, with substantial bilateral support from France, Germany, and the UK. ${ }^{61}$ The Obama Administration's Global Health Security Agenda, with 44 partner countries, is injecting new resources to prevent and mitigate future health threats. ${ }^{62}$

Lower-income countries including Cuba and Uganda offered human resources and skills..$^{63,64}$ The African Union Support to Ebola Outbreak in West Africa (ASEOWA) sent more than 800 health workers. ${ }^{65}$ Yet some states imposed travel restrictions and quarantines contrary to the demands of WHO and the UN, hindering the response. In an interconnected world, every state has a national security interest in containing novel pathogens that can transcend borders.

\section{Non-governmental organisations: Médecins Sans Frontières}

Médecins Sans Frontières-along with others, including Partners In Health and Samaritan's Purse-showed the importance of non-governmental organisations by leading the medical response and sounding a global alert. Médecins Sans Frontières deployed more than 1300 international and 4000 local staff. ${ }^{66}$ The organisation admitted 8100 patients to its eight treatment centres by mid-February. Of nearly 5000 confirmed cases, 2300 survived. ${ }^{67}$ Médecins Sans Frontières organised community-based teams to educate the public and to trace contacts. $^{68}$ Its courage came with a price, as 27 members of staff became infected, mostly in the community. ${ }^{66}$ In future outbreaks, until health systems can stand on their own, international non-governmental organisations will remain invaluable service providers and independent sources of information.

\section{Private sector}

When the Ebola outbreak began, despite periodic previous outbreaks, no approved vaccines or treatments had been developed. Pharmaceutical companies had 
Panel: The reform agenda: assuring global health security

\section{An empowered WHO}

Funding: commensurate with global mandate and under Director-General's control

Technical excellence: diverse staff with multisectoral capabilities

Operational capacities: rapid deployment of economic and human resources

Normative standards: setting priorities and ensuring compliance

Regional offices: regional knowledge and consistency with headquarters

Engaging non-state parties: harnessing the potential of civil society

\section{National health capacities}

Global health workforce reserve

Emergency contingency fund

Pandemic emergency facility

International health systems fund

Strengthening the International Health Regulations

Stronger state duties to build core capacities

Revise algorithm for declaring a Public Health Emergency of International Concern

Independent monitoring and transparency

Compliance enhancing mechanisms

little incentive to invest in countermeasures for unpredictable outbreaks and in poor countries. Even major government and philanthropic funders often overlooked diseases with low global burdens. The Ebola epidemic should change these incentive structures, with public-private partnerships needed to pursue solutions for diseases with epidemic potential, however rare. ${ }^{69}$ The private sector's contribution to pandemic preparedness extends beyond medical countermeasures to information technology (eg, mobile telephones, apps, and data systems), logistics (eg, transporting equipment and supplies), and innovative financing (eg, the insurance and financial sectors).

\section{International Health Regulations: the governing legal framework}

International law and national implementing legislation can be powerful means for a more effective global health system. The IHR, the governing instrument for global health security, displayed flaws during the Ebola outbreak. States widely ignored its capacity-building mandates. After the 2009 influenza A H1N1 pandemic, the WHO independent Review Committee warned that the world was not on track to meet core capacities. Guinea, Liberia, and Sierra Leone had not even reported their progress. ${ }^{70}$ The IHR contains permissive language on capacity building, requiring states "to collaborate with each other, to the extent possible." ${ }^{11}$ The World Health Assembly should revise the IHR to provide concrete steps for building health system capacities. A donor conference, similar to the Global Fund's replenishment mechanism, could infuse funding toward that goal. ${ }^{72}$

States disregarded not only the IHR's capacity building mandate, but also the Director-General's temporary IHR recommendations. ${ }^{14}$ Some governments lacked the capacity to comply, with the Director-General unrealistically, in our opinion, asking post-conflict states with some of the world's weakest infrastructure and most poorly financed health systems to themselves ensure sufficient treatment centres, trained staff, and protective equipment. Other states merely chose not to comply, for example, by imposing quarantines and travel restrictions without scientific justification.

The IHR should contain compliance-enhancing mechanisms, including independent monitoring of country performance and public reporting. Currently, states assess their own compliance and the WHO database merely aggregates country data. An independent certification-ofcompliance system, as occurs with polio eradication, could hold states to account. The World Health Assembly should update the IHR to ensure independence, rigorous assessment, and transparency. ${ }^{72}$ The Assembly should also amend the IHR's decision instrument on when to declare a PHEIC (panel) to include fragile health systems, behavioural practices, and public distrust.

The Director-General's sole power to call an Emergency Committee meeting and declare a PHEIC could be supplemented by an independent working group, regularly assessing potential global health threats, reporting publicly, and recommending that the DirectorGeneral convene an Emergency Committee. ${ }^{34}$ To improve transparency, the Emergency Committee or the Director-General should provide reasons for their decisions, as well as a timeline of WHO's response and resource mobilisation.

\section{Mobilising human and financial resources: preparing for a crisis}

The delay in mobilising financing and human resources showed the heavy costs of a failure to prepare. Planning for rapid mobilisation should be combined with strengthening health systems to build country capacity. The subsequent capacity-building reforms would better ensure health security, both regionally and worldwide.

\section{Global health workforce reserve}

Health worker shortages, combined with the human resource-intense response, demanded international support. Yet the flow of health workers was far beneath the need. In late October, 2014, part of the epidemic's worst phase, there was "a huge gap" in trained workers, with the UN estimating 1000 foreign health workers still needed. ${ }^{73}$ As Ebola peaked in December in Sierra Leone, treatment centres still had staff deficiencies. ${ }^{74}$

WHO does not have staff to serve as front-line service providers, and developing this capacity would be costly and inefficient. Rather, the organisation should draw human resources from networks such as the Global Outbreak Alert and Response Network (GOARN)-a collaboration of institutions, which pools human resources and equipment. ${ }^{36,75}$ WHO should certify reserve workforce outbreak response and health 
emergency competencies. Importantly, well trained health workers would serve their communities, deployed internationally only when needed to quell a major outbreak.

Obstacles to rapid deployment should be removed, such as national registration or licensing, liability, and visa delays. Workers should be fairly compensated, with safe working conditions. If workers become ill, WHO should ensure treatment in country or through medical evacuation.

\section{Emergency contingency fund}

By the end of July, 2014, WHO reported that only $\$ 7$ million had been contributed to combat Ebola. ${ }^{12}$ Even when funds were promised, large gaps remained between commitments and disbursements. ${ }^{76}$ Funding has now reached billions of dollars. Yet by early 2015, there were already signs of donor fatigue. ${ }^{\pi}$ The slow initial response enabled Ebola to escalate, whereas political will could now wane during the final crucial phases.

The outbreak reminded us that mobilising funds only after a crisis hits is ineffective. WHO never implemented the 2011 IHR Review Committee recommendation for a standing $\$ 100$ million contingency fund to be released in a declared emergency. ${ }^{70}$ The 2015 Executive Board, however, directed the Director-General to report to the World Health Assembly on more expansive funding needs, "the preparedness, surveillance and response work of WHO". ${ }^{36}$ A contingency fund would have to include new resources so it does not erode the agency's overall budget. In view of the experience with Ebola, the fund will have to go above the $\$ 100$ million initially proposed.

\section{A pandemic emergency facility}

The World Bank has proposed a pandemic emergency facility to fund future pandemic response, including health workers, medicines, supplies, and information systems. The facility would frontload funds to be available in a pandemic, supported by long-term donor pledges and the private sector. ${ }^{78}$ By use of an insurance model, for example, states and development partners would insure against epidemic risks, with premiums lowered as preparedness improves. ${ }^{79}$ Insurance payouts would be triggered by a predefined emergency event. This model takes advantage of state and private interests in lowering future risks of a public health crisis.

\section{International health system fund}

Neither the WHO contingency fund nor the World Bank's emergency facility would robustly fund the IHR's core capacities or health systems. Disease-specific initiatives such as the Global Fund and GAVI have improved health systems, but remain insufficient.

Health economists estimate that one-third to one-half of new health financing should be directed to health system strengthening, ${ }^{80,81}$ yet less than $7 \%$ of international funds are devoted to that goal. ${ }^{82}$ Without a new approach, international funding will not meet health systemstrengthening needs. Therefore, we propose a multibillion dollar international health systems fund. ${ }^{83}$ The Fund could be under the purview of the Global Fund, with an expanded mandate, increased funding, and governance reforms to ensure broad expertise and participation. States could pay dues assessed at levels based on UN and WHO contributions, the equitable contributions framework, ${ }^{84}$ or other metrics, with reciprocal national investments.

Alternatively, the International Health System Fund could be housed under a new public-private partnership, including key international organisations (eg, WHO and the World Bank), governments, civil society, and communities. The Global Fund and GAVI chairs could be board members, ensuring synergy among the funds. The new Fund could borrow features from both global health funds, such as the Global Fund's inclusive Country Coordination Mechanisms, human rights strategy, and focus on marginalised populations, along with GAVI's cofinancing requirement.

\section{The need to act now}

Action now on WHO and other reforms to the global health system is crucial, before the political moment passes. The World Health Assembly should affirm its commitment to the workforce reserve and contingency fund, even as details may require further development. It should call for the Director-General to develop a needs-based budget, as well as options for reform of regional governance and deepened civil society engagement, with final decisions next year. The Global Fund and GAVI Board could hold a joint board meeting to determine the possibility of their incorporating an international health system fund. If they decline, the UN should launch this Fund, replicating its catalytic role for the Global Fund. ${ }^{85}$

\section{A global health system for all}

The Ebola outbreak in west Africa revealed the incoherence and inequity of the global health system. Impoverished communities and countries suffer most, but everyone is at risk. The west African crisis, combined with the post-2015 Sustainable Development Goals, provides a rare political opportunity for sweeping reforms. Robust national health systems, a 21st century WHO, a strong IHR with state compliance, and sustainable human and financial resources would transform the global health system. These reforms would not only keep populations secure against pandemic threats, but would also ensure health and safety for all needs through rights-based universal health coverage. This is a global health framework that is achievable in the aftermath of a tragic epidemic that needlessly took more than 10000 lives in one of the world's poorest regions. 
Contributors

LOG and EAF contributed equally to this paper.

\section{Declaration of interests}

LOG is Director of the WHO Collaborating Center for Public Health Law and Human Rights. EAF declares no competing interests.

References

1 Back to the start. Ebola in Guinea. Economist 2015; 34.

2 Baize S, Pannetier D, Oestereich L, et al. Emergence of Zaire Ebola virus disease in Guinea. N Engl J Med 2014; 371: 1418-25.

3 Marchione M. Mission unaccomplished: containing Ebola in Africa. Associated Press, Oct 18, 2014. http://news.yahoo.com/missionunaccomplished-containing-ebola-africa-140654240.html (accessed Feb 6, 2015).

4 Sack K, Fink S, Belluck P, Nossiter A. Ebola's deadly escape. The New York Times, Dec 30, 2014. http://www.nytimes. com/2014/12/30/health/how-ebola-roared-back.html (accessed Feb 6, 2015).

5 Nishi N. Quarantine for Ebola Lifted in Liberia Slum. The New York Times, Aug 30, 2014. http://www.nytimes. com/2014/08/30/world/africa/quarantine-for-ebola-lifted-in-liberiaslum.html (accessed April 22, 2015).

6 Johns Hopkins Bloomberg School of Public Health. Creating trust in the time of Ebola. http://www.jhsph.edu/news/news-releases/2014/ creating-trust-in-the-time-of-ebola.html (accessed Feb 6, 2015).

7 Integrated Regional Information Networks. Overcoming Ebola stigma takes time. http://www.irinnews.org/report/100775/ overcoming-ebola-stigma-takes-time (accessed Feb 6, 2015).

8 Médecins Sans Frontières. A mixed welcome for homecoming Ebola survivors. http://www.doctorswithoutborders.org/article/mixedwelcome-homecoming-ebola-survivors (accessed Feb 6, 2015).

9 Thompson D. Ebola's deadly spread in Africa driven by public health failures, cultural beliefs. National Geographic. http://news. nationalgeographic.com/news/2014/07/140702-ebola-epidemic-feverworld-health-guinea-sierra-leone-liberia/ (accessed Feb 4, 2015).

10 Médecins Sans Frontières. Ebola in west Africa: epidemic requires massive deployment of resources. http://www.msf.org/article/ ebola-west-africa-epidemic-requires-massive-deployment-resources (accessed Feb 9, 2015).

11 WHO. Nigeria is now free of Ebola virus transmission. http://www. who.int/mediacentre/news/ebola/20-october-2014/en/index2.html; 2014 (accessed April 22, 2015).

12 WHO. Governments of Guinea, Liberia, and Sierra Leone. EVD outbreak response plan in west Africa. http://www.who.int/csr/ disease/ebola/evd-outbreak-response-plan-west-africa-2014.pdf (accessed Oct 2, 2014).

13 UN. Ebola virus disease outbreak: overview of needs and requirements. https://docs.unocha.org/sites/dms/CAP/Ebola_ outbreak_Sep_2014.pdf (accessed Oct 2, 2014).

14 WHO. WHO statement on the meeting of the International Health Regulations emergency committee regarding the 2014 Ebola outbreak in west Africa. http://www.who.int/mediacentre/news/ statements/2014/ebola-20140808/en/ (accessed Sept 28, 2014).

15 Cheng M,Satter R. Emails: UN health agency resisted declaring Ebola emergency. Associated Press, March 20, 2015. http://bigstory. ap.org/article/ea7199795faa48989449131404b7043e/emails-unhealth-agency-resisted-declaring-ebola-emergency (accessed March 20, 2015).

16 UN Security Council. Resolution 2177. http://www.un.org/en/ga/ search/view_doc.asp?symbol=S/RES/2177\%20(2014) (accessed Sept 28, 2014).

17 UN Security Council. UN General Assembly Sixty-Ninth Session. Ebola-identical letters dated 17 September 2014 from the SecretaryGeneral to Security Council/General Assembly. UN Doc. A/69/389-S/2014/679. http://www.un.org/en/ga/search/view_doc. asp? symbol=A/69/389 (accessed Oct 2, 2014).

18 Meltzer MI, Atkins CY, Santibanez S, et al. Estimating the future number of cases in the Ebola epidemic_Liberia and Sierra Leone, 2014-2015. MMWR Surveill Summ 2014; 63: 1-14.

19 Fernandez M and Philipps D. Ebola Patient Dies in Dallas, Fueling Alarm. The New York Times, Oct 9, 2014. http://www.nytimes. com/2014/10/09/us/ebola-us-thomas-eric-duncan.html (accessed April 22, 2015)

20 Two US nurses free of virus. BBC News, Oct 25, 2014. http://www. bbc.com/news/world-us-canada-29749283 (accessed April 22, 2015).
21 Gostin LO, Hodge JG Jr, Burris S. Is the United States prepared for Ebola? JAMA 2014; 312: 2497-98.

22 UN. Nimble and flexible approach needed to bring new Ebola cases to zero-UN. http://www.un.org/apps/news/story.asp?NewsID=49479\#. VOdxakKzvMg (accessed Feb 20, 2015).

23 Gostin LO, Waxman HA, Foege W. The president's national security agenda: curtailing Ebola, safeguarding the future. JAMA 2015; 313: 27-28.

24 Clift C. Devil in the detail for WHO's Ebola resolution. Chatham House expert comment. Jan 27, 2015. http://www.chathamhouse. org/expert/comment/16763 (accessed Feb 20, 2015).

25 UNMEER. Funding the Ebola response. https://ebolaresponse. un.org/funding-ebola-response (accessed March 16, 2015).

26 UNMEER. Ebola outbreak: updated overview of needs and requirements for January-June 2015. http://ebolaresponse.un.org/ sites/default/files/onr2015.pdf (accessed Feb 20, 2015).

27 Dennis B, Sun LH. The new Ebola target number: zero cases. Washington Post. http://www.washingtonpost.com/national/ health-science/next-phase-in-ebola-fight-getting-tozero/2015/02/04/4f5b3ed4-a570-11e4-a7c2-03d37af98440_story. html (accessed Feb 20, 2015).

28 WHO. Ebola situation report, Feb 18, 2015. http://apps.who.int/ ebola/en/ebola-situation-report/situation-reports/ebola-situationreport-18-february-2015 (accessed Feb 20, 2015).

29 WHO. Ebola situation report, April 22, 2015. http://apps.who.int/ ebola/current-situation/ebola-situation-report-22-april-2015-0 (accessed April 22, 2015).

30 Gostin LO, Friedman EA. Ebola: a crisis in global health leadership Lancet 2014; 384: 1323-25.

31 Global Health Workforce Alliance and WHO. A universal truth: no health without a workforce. http://www.who.int/workforcealliance/ knowledge/resources/GHWA-a_universal_truth_report.pdf?ua=1 (accessed March 16, 2015).

32 Center for Strategic and International Studies. The road to recovery: rebuilding Liberia's health system. http://csis.org/files/ publication/120822_Downie_RoadtoRecovery_web.pdf (accessed March 16, 2015)

33 WHO. Global Health Observatory data repository, absolute numbers, data by country. http://apps.who.int/gho/data/node. main.A1443?lang=e (accessed Jan 20, 2015).

34 O'Neill Institute for National and Global Health Law. O'Neil Institute: reflections from the frontline of the Ebola response with Dr. Dan Lucey. http://apps.law.georgetown.edu/webcasts / eventDetail.cfm?eventID=2555 (accessed Feb 17, 2015)

35 WHO. WHO Constitution. http://whqlibdoc.who.int/hist/official_ records/constitution.pdf (accessed Jan 3, 2015).

36 WHO. WHO Executive Board special session on Ebola resolution. Ebola: ending the current outbreak, strengthening global preparedness and ensuring WHO's capacity to prepare for and respond to future large-scale outbreaks and emergencies with health consequences. http://apps.who.int/gb/ebwha/pdf_files/ EBSS3/EBSS3_R1-en.pdf (accessed Feb 25, 2015).

37 Nebehay S, Lewis B. WHO slashes budget, jobs in new era of austerity. May 19, 2011. Reuters. http://www.reuters.com/ article/2011/05/19/us-who-idUSTRE74I5I320110519 (accessed March 16, 2015)

38 WHO. Proposed programme budget 2014-2015. http://apps.who. int/gb/ebwha/pdf_files/WHA66/A66_7-en.pdf (accessed Sept 28, 2014)

39 Fink S. Cuts at WHO hurt response to Ebola crisis. Sept 3, 2014 The New York Times. http://www.nytimes.com/2014/09/04/world/ africa/cuts-at-who-hurt-response-to-ebola-crisis.html (accessed Sept 28, 2014).

40 Gostin LO, Friedman EA. Towards a framework convention on global health: a transformative agenda for global health justice. Yale J Health Policy Law Ethics 2013; 13: 1-75. http:// digitalcommons.law.yale.edu/cgi/viewcontent.cgi?article=1201\&co ntext=yjhple\&sei-redir=1\&referer=http\%3A\%2F\%2Fus.yhs4 search.yahoo.com\%2Fyhs\%2Fsearch\%3Fp\%3DTowards\%2Ba\%2B framework\%2Bconvention\%2Bon\%26fr\%3Dgoodsearchyhsif\%26b\%3D1\%26param1\%3D915243895\#search=\%22Towar ds\%20framework\%20convention\%22 (accessed April 23, 2015).

41 Hook BH. The U.N. agency that bungled Ebola. Wall Street J. Oct 22, 2014. 
42 Ellison C. Davos Ebola panel advances architecture for robust \& responsive global health security. Jan 22, 2015. http://blogs. oliverwyman.com/healthcare/2015/01/22/davos-ebola-paneladvances-architecture-for-robust-responsive-global-health-security/ (accessed Feb 26, 2015)

43 UN Development Group-Western and Central Africa. A call for national and regional containment, recovery and prevention. http://www.africa.undp.org/content/dam/rba/docs/Reports/ebolawest-africa.pdf (accessed March 16, 2015).

44 World Bank. Summary on the Ebola Recovery Plan: Guinea. http://www.worldbank.org/en/topic/ebola/brief/summary-on-theebola-recovery-plan-guinea (accessed April 22, 2015).

45 World Bank. Summary on the Ebola Recovery Plan: Liberia. http://www.worldbank.org/en/topic/ebola/brief/summary-on-theebola-recovery-plan-liberia-economic-stabilization-and-recoveryplan-esrp (accessed April 22, 2015).

46 World Bank. Summary on the Ebola Recovery: Sierra Leone. http://www.worldbank.org/en/topic/ebola/brief/summary-on-theebola-recovery-plan-sierra-leone (accessed April 22, 2015).

47 Boseley S. World Health Organization admits botching response to Ebola outbreak. Oct 17, 2014. Guardian. http://www.theguardian. com/world/2014/oct/17/world-health-organisation-botched-ebolaoutbreak (accessed Feb 9, 2015).

48 Burci GL, Vignes CH. World Health Organization. The Hague, London, New York: Kluwer Law International: 2004: 57.

49 WHO Regional Committee for Europe. Resolution: governance of the Regional Committee for Europe. http://www.euro.who.int/_ data/assets/pdf_file/0004/217741/63rs07e_Governance.pdf?ua=1 (accessed Feb 27, 2015).

50 WHO. WHO reform: overview of reform implementation: report of the Secretariat. http://apps.who.int/gb/ebwha/pdf_files/EB136/ B136_7-en.pdf (accessed Feb 27, 2015).

51 WHO. Streamlining of the work of the governing bodies and harmonization and alignment of the work of regional committees. http://apps.who.int/gb/ebwha/pdf_files/EB132/B132_5Add3-en.pdf (accessed March 1, 2015).

52 WHO. Framework of engagement with non-state actors: report by the Secretariat. http://apps.who.int/gb/ebwha/pdf_files/EB136/ B136_5-en.pdf (accessed March 3, 2015).

53 WHO. Key issues for the development of a policy on engagement with nongovernmental organizations: Report by the DirectorGeneral. http://apps.who.int/gb/ebwha/pdf_files/EB132/ B132_5Add2-en.pdf?ua=1 (accessed March 3, 2015).

54 WHO. Revised human resource strategy. http://www.who.int/about/ who_reform/ebpbac-hr-strategy.pdf?ua=1 (accessed Feb 28, 2015).

55 World Health Organization. Too big to ail. Economist 2014; 13.

56 Center for Strategic and International Studies. Audio: creating UNMEER: a discussion with Anthony Banbury. http://csis.org/ multimedia/audio-creating-unmeer-discussion-anthony-banbury (accessed March 4, 2015).

57 United Nations. United Nations Charter. Article 25. http://www.un.org/ en/documents/charter/chapter5.shtml (accessed March 4, 2015).

58 World Bank. Ebola: World Bank Group provides new financing to help Guinea, Liberia and Sierra Leone recover from Ebola emergency. http://www.worldbank.org/en/news/press-release/2015/04/17/ebolaworld-bank-group-provides-new-financing-to-help-guinea-liberiasierra-leone-recover-from-ebola-emergency (accessed April 22, 2015).

59 World Bank. Ebola: World Bank Group mobilizes emergency funding to fight epidemic in west Africa. Aug 4, 2014. http://www. worldbank.org/en/news/press-release/2014/08/04/ebola-worldbank-group-mobilizes-emergency-funding-for-guinea-liberia-andsierra-leone-to-fight-epidemic (accessed April 22, 2015).

60 World Bank. Ebola: new World Bank Group study forecasts billions in economic loss if epidemic lasts longer, spreads in west Africa. http://www.worldbank.org/en/news/press-release/2014/10/08/ebolanew-world-bank-group-study-forecasts-billions-in-economic-loss-ifepidemic-lasts-longer-spreads-in-west-africa (accessed Feb 17, 2015).

61 UN Office for the Coordination of Humanitarian Affairs. Ebola virus outbreak-west Africa. April 2014, Table B: total funding per donor (appeal plus other*) as of March 6,2015. http://fts.unocha.org/reports/ daily/ocha_R24_E16506__1503060301.pdf (accessed March 5, 2015).

62 US Department of Health and Human Services. Global Health Security Agenda White House Event, Washington, DC, Sept 26, 2014. http://www.globalhealth.gov/global-health-topics/global-healthsecurity/ghswhitehouseevent (accessed March 24, 2015).
63 Editorial. Cuba's impressive role on Ebola. The New York Times. http://www.nytimes.com/2014/10/20/opinion/cubas-impressiverole-on-ebola.html (accessed March 5, 2015).

64 WHO Regional Office for Africa. Uganda health workers supporting west Africa on Ebola response. http://www.afro.who.int/en/uganda/ press-materials/item/6898-uganda-health-workers-supporting-westafrica-on-ebola-response.html (accessed March 5, 2015).

65 South African Government News Agency. West Africa: Ebolasecond group of health workers sent to west Africa. http://allafrica. com/stories/201502161557.html (accessed March 5, 2015).

66 Médecins Sans Frontières. Pushed to the limit and beyond: a year into the largest ever Ebola outbreak. http://www.msf.org/sites/msf.org/ files/msflyearebolareport_en_230315.pdf (accessed March 23, 2015).

67 Médecins Sans Frontières. Ebola crisis update February 12, 2015. http://www.msf.org/article/ebola-crisis-update-12-february-2015 (accessed March 4, 2015).

68 Médecins Sans Frontières. Ebola: to create awareness among a population, you must listen. http://www.msf.org/article/ebola\%E2\%80\%9C-create-awareness-among-population-you-mustlisten\%E2\%80\%9D (accessed March 4, 2015).

69 Mullan Z. Ebola vaccines: an uncertain future? Lancet Glob Health 2015; 3: e113.

70 WHO. Report of the Review Committee on the functioning of the International Health Regulations (2005) in relation to the pandemic (H1N1) 2009. http://apps.who.int/gb/ebwha/pdf_files/WHA64/ A64_10-en.pdf (accessed March 6, 2015).

71 WHO. International Health Regulations (2005). Article 4. http:// whqlibdoc.who.int/publications/2008/9789241580410_eng.pdf (accessed March 6, 2015).

72 Lancet. Ebola: what lessons for the International Health Regulations? Lancet 2014; 384: 1321.

73 Boseley S. World Bank pledges $\$ 100 \mathrm{~m}$ to send health workers to Ebola-hit countries. The Guardian. http://www.theguardian.com/ world/2014/oct/30/world-bank-invests-foreign-health-workers-ebola (accessed March 8, 2015).

74 Nebehay S. Ebola still spreading in western Sierra Leone, Guinea's forest. Reuters. http://www.reuters.com/article/2014/12/09/us-healthebola-who-idUSKBNOJM24X20141209 (accessed March 8, 2015).

75 WHO. Global Outbreak \& Alert Response Network (GOARN). http:// www.who.int/csr/outbreaknetwork/en/ (accessed Feb 25, 2015).

76 Statement of the Co-Chairs. Ebola: "From Emergency to Recovery"; Brussels, Belgium; March 3, 2015. https://ebolaresponse.un.org/ sites/default/files/statement_of_the_co-chairs_-_brussels_-_3_ march_2015.pdf (accessed March 9, 2015).

77 Ebola: Liberia's Johnson Sirleaf urges 'Marshall Plan.' BBC News. http://www.bbc.com/news/world-africa-31705594 (accessed March 9, 2015).

78 World Bank. Pandemic emergency facility: frequently asked questions. http://www.worldbank.org/en/topic/pandemics/brief/ pandemic-emergency-facility-frequently-asked-questions (accessed March 9, 2015).

79 World Bank. World Bank Group President: world is 'dangerously unprepared' for future pandemics. http://www.worldbank.org/en/ news/press-release/2015/01/27/world-bank-group-president-worlddangerously-unprepared-future-pandemics (accessed March 9, 2015).

80 Jamison DT, Summers LH, Alleyne G, et al. Global health 2035 a world converging within a generation. Lancet 2013; 382: 1898-955.

81 Taskforce on Innovative International Financing for Health Systems. Constraints to scaling up and costs: Working Group 1 report. http:// www.internationalhealthpartnership.net/fileadmin/uploads/ihp/ Documents/Results__Evidence/HAE_results__lessons/ WORKING\%20GROUP\%201\%20REPORT\%20-\%20Constraints\%20 to\%20Scaling\%20Up\%20and\%20Costs.pdf (accessed Feb 12, 2015).

82 Dieleman JL, Graves C, Johnson E, et al. Tracking development assistance for health from source to health focus area, 1990-2014. JAMA (in press).

83 Gostin LO. Ebola: towards an International Health Systems Fund. Lancet 2014; 384: e49-51.

84 Rivers B. Recommended country-by-country donations to the Global Fund. Global Fund Observer, May 21, 2004. http://www. aidspan.org/gfo_article/recommended-country-country-donationsglobal-fund (accessed March 21, 2015).

85 UN General Assembly. Declaration of Commitment on HIV/AIDS. Resolution S-26/2. June 27, 2001. http://www.un.org/ga/aids/docs/ aress262.pdf (accessed April 23, 2015). 


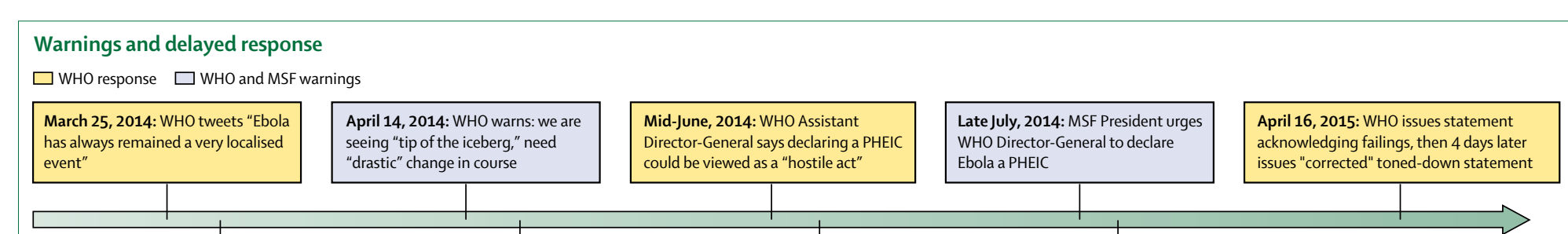

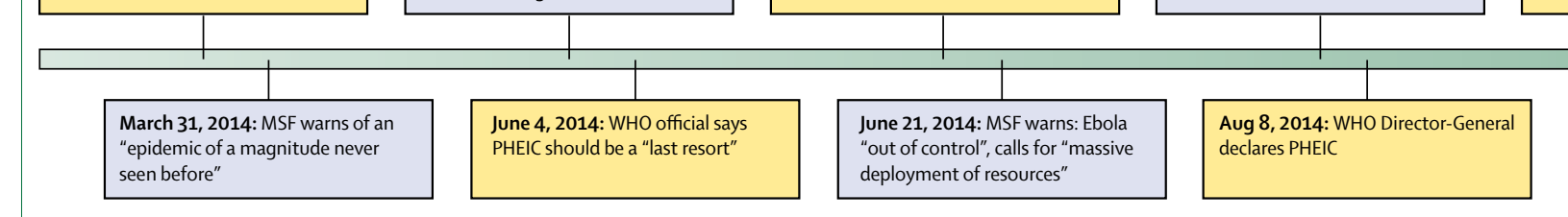

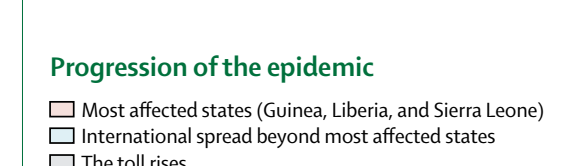
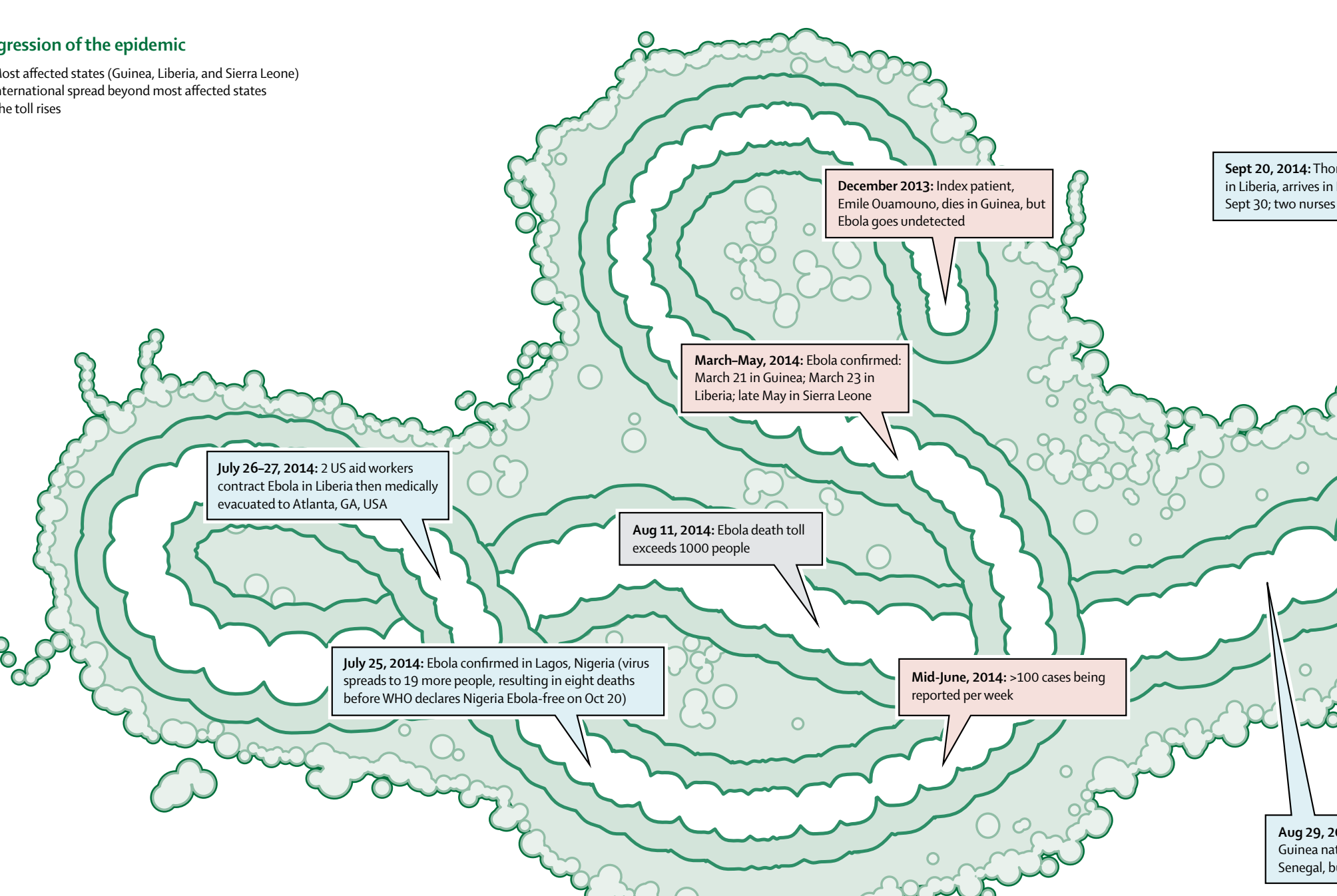

ternational mobilisation

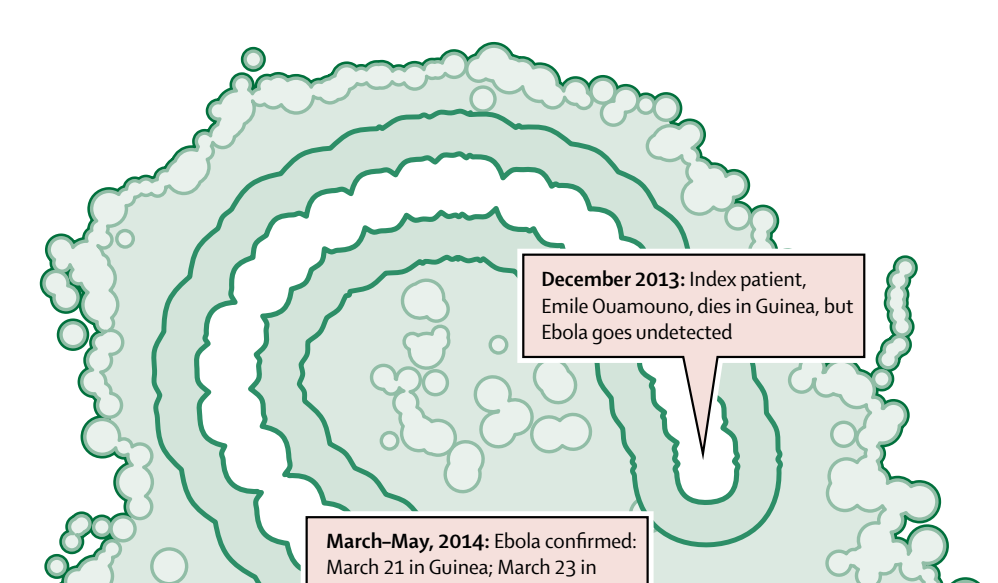

Fear, stigma, and separation

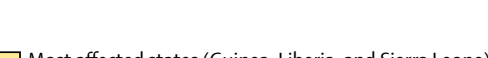

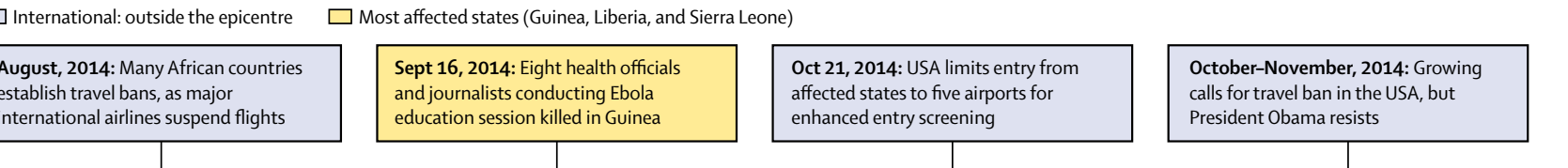

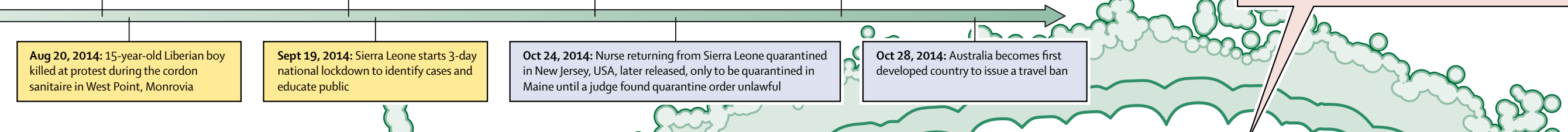

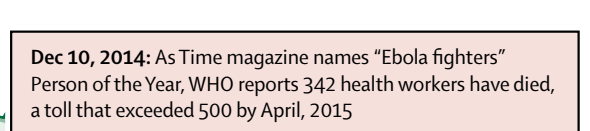

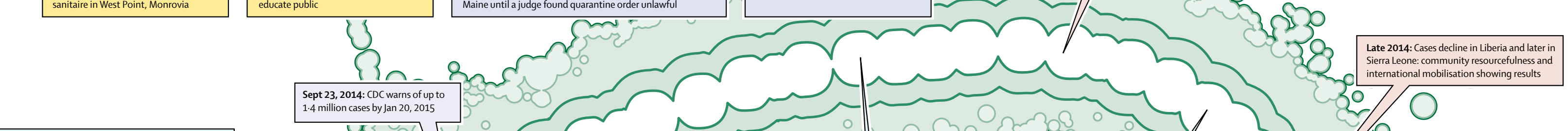

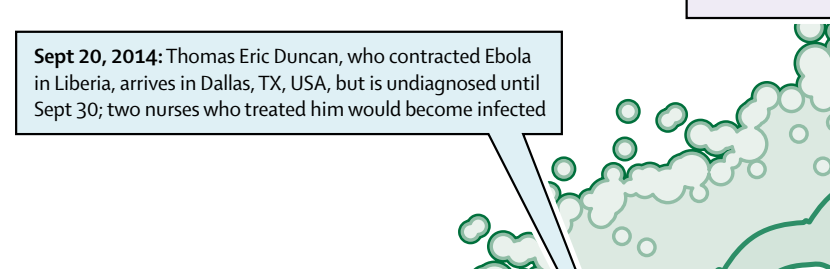
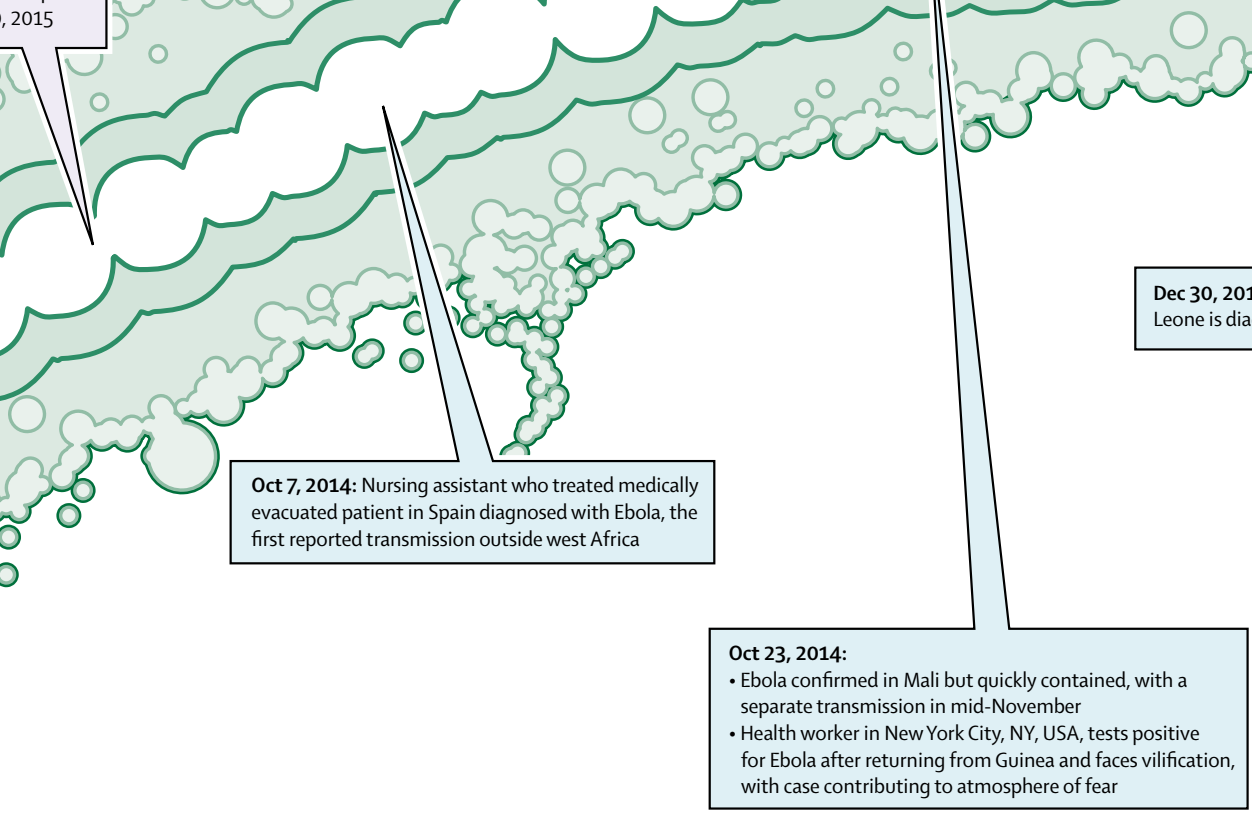

a

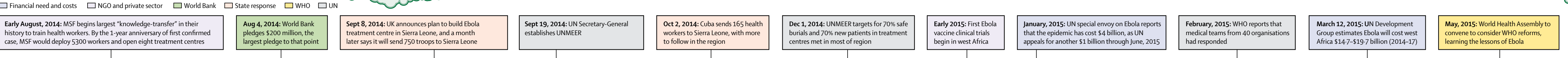

